\title{
AKIBAT HUKUM PEMEKARAN KELURAHAN DI KECAMATAN TAMPAN KOTA PEKANBARU BERDASARKAN PERATURAN DAERAH KOTA PEKANBARU NOMOR 5 TAHUN 2008 TENTANG PENYELENGGARAAN ADMINISTRASI KEPENDUDUKAN
}

\author{
Eka Widia Ningsih \\ Paralegal pada Organisasi bantuan Hukum Pusat Advokasi Hukum dan \\ Hak Asasi manusia (PAHAM) Riau, Email: Ekawidia65@gmail.com
}

\begin{abstract}
Abstrack
That the existence of an urban division in the tampan district of Pekanbaru City has caused a change of address in the community's residence, which required the community to make changes to the address on population documents, which than also re adjust other data in accordance with the changes made. As in its administration it takes quite a long time and also makes it difficult for the community and will result in various othe administrations both within the Pekanbaru city administration environment and acros sectors which are no longer under the auspices or responsibilities of the Pekanbaru city government. Inhibiting factors in changing the address of population documents caused by the division of villages in the city of pekanbaru tampan district include the increasing number of people who will make changes, the lack of existing infrastructure, lack of employee knowledge of policies that must be carried out and the lack of public awareness and participation in implementing policies determined by the government.
\end{abstract}

Key words: Due to Laws, Expansion, regional regulations

\begin{abstract}
Abstrak
Bahwa Adanya pemekaran kelurahan di Kecamatan Tampan Kota Pekanbaru menyebabkan terjadinya perubahan alamat pada tempat tinggal masyarakat yang mengharuskan masyarakat untuk melakukan perubahan alamat pada dokumen kependudukan yang kemudian juga harus kembali meyesuaikan data lain sesuai dengan perubahan yang dilakukan. sebagaimana dalam pengurusannya memakan waktu yang cukup lama dan juga menyulitkan masyarakat dan akan berakibat terhadap berbagai administrasi lain baik dalam lingkungan pemerintahan Kota Pekanbaru mapun lintas sektor yang tidak lagi dibawah naungan
\end{abstract}


atau tanggung jawab pemerintah kota pekanbaru. Faktor-faktor penghambat dalam perubahan alamat dokumen kependudukan yang disebabkan pemekaran kelurahan di kecamatan Tampan kota Pekanbaru diantaranya adalah Meningkatnya jumlah masyarakat yang akan melakukan perubahan, Kurangnya Blangko KTP-Elektronik baik perubahan maupun pengurusanbaru, Kurangnya sarana prasarana yang ada,Kurangnya pengetahuan pegawai terhadap kebijakan yang harus dijalankan dan Kurangnya kesadaran dan partisipasi masyarakat dalam melaksanakan kebijakan yang ditetapkan pemerintah.

Kata kunci: Akibat Hukum, Pemekaran, Peraturan Daerah

\section{PENDAHULUAN}

Kota Pekanbaru sebagai salah satu Kota Administratif di Indonesia yang baru saja melakukan Otonomi Daerah dengan pemekaran kelurahan dibeberapa kecamatan. Kecamatan Tampan sebagai salah satu Kecamatan terluas dan terbanyak jumlah penduduknya ikut serta dalam pemekaran Kelurahan tersebut. Luas wilayah Kecamatan Tampan adalah $4.872 \mathrm{KM}^{2}$ atau sama dengan 9,46\% dari luas kota Pekanbaru, yang sebagian besar wilayahnya digunakan untuk perumahan / perkarangan dengan didukung oleh 4 kelurahan ${ }^{1}$, dengan adanya pemekaran wilayah tersebut maka Kecamatan Tampan menjadi 9 kelurahan ${ }^{2}$.

Dalam Peraturan Daerah Kota Pekanbaru Nomor 5 Tahun 2008 Tentang Penyelenggaraan Administrasi Kependudukan Pasal 6 disebutkan bahwa "Dalam hal terjadi perubahan alamat penduduk, Instansi Pelaksana wajib menyelenggarakan penerbitan perubahan dokumen Pendaftaran Penduduk". Dalam hal di atas sesuai dengan terjadinya pemekaran wilayah di kecamatan Tampan, maka terjadi perubahan alamat-alamat setiap individu masyarakat. Yaitu masyarkat akan mengajukan perubahan terhadap kartu identitasnya baik itu Kartu Tanda Penduduk (KTP) Maupun Kartu Keluarga (KK) yang kemudian akan berakibat hukum terhadap administrasi kependudukan lainnya

\footnotetext{
${ }^{1}$ http://tampan.pekanbaru.go.id/2015-08-14-02-58-43/profil-kecamatan

2 Peraturan Daerah Kota pekanbaru Nomor 4 Tahun 2016 Tentang Pembentukan Kelurahan Di Kota Pekanbaru.
} 
seperti perubahan surat kepemilikan tanah,surat kendaraan dan dalam hal pembayaran pajak.

Berdasarkan permasalahan diatas maka penulis melakukan penelitian tentang Akibat Hukum Pemekaran Kelurahan di Kecamatan Tampan Kota Pekanbaru Berdasarkan Peraturan Daerah Kota Pekanbaru No 5 Tahun 2008 Tentang Penyelenggaraan Administrasi Kependudukan, secara khusus membahas akibat hukum yang terjadi dengan adanya pemekaran kelurahan di kecamatan Tampan kota Pekanbaru dan membahas faktor-faktor penghambat dalam perubahan alamat yang disebabkan pemekaran kelurahan di kecamatan Tampan kota Pekanbaru.

Tujuan penelitian adalah Untuk mengetahui akibat hukum pemekaran kelurahan di Kecamatan Tampan Kota Pekanbaru. Untuk mengetahui faktor-faktor penghambat perubahan alamat dengan adanya pemekaran kelurahan di Kecamatan Tampan Kota Pekanbaru.

\section{Metodologi Penelitian}

Jenis penelitian ini adalah penelitian hukum sosiologis. populasi dalam penelitian ini adalah masyarakat Kecamatan Tampan Kota Pekanbaru yang termasuk dalam wilayah pemekaran Kelurahan. Dari populasi diatas penulis mengambil sampel dengan menggunakan metode Multistage sampling yaitu gabungan antara probability dan non probability. Dalam pengambilan sampel dengan menggunakan Random sampling atau Probability sampling, atau sampling acak penulis menggunakan jenis area/ Cluster sampling. Dan kemudian menggunakan purposive sampling atau Sampling judgmental yaitu sampel yang dipilih berdasarkan pertimbangan/penelitian subjektif dari peneliti, jadi dalam hal ini peneliti menentukan sendiri responden mana yang dianggap dapat mewakili populasinya.

Data yang diperoleh dalam penelitan ini yaitu data primer, data sekunder, dan data tersier. Data dikumpulkan Melalui observasi, 
wawancara, kajian kepustakaan dan kuisioner yang kemudian di analisis dengan teknik Deskriptif Kualitatif dengan metode induktif dan deduktif.

\section{LANDASAN TEORI}

\section{DASAR HUKUM PEMEKARAN DAERAH}

Setiap Negara didirikan atas dasar falsafah tertentu, falsafah itu adalah merupakan perwujudan dari rakyatnya. Karena itu setiap Negara mempunyai falsafah yang berbeda. ${ }^{3}$ Sesuai dengan amanat UndangUndang Dasar 1945 Pasal 18 ayat (7) bahwa susunan dan tata cara penyelenggaraan pemerintah daerah diatur dalam Undang-Undang, maka pada tahun 2004 ditetapkan Undang-Undang Nomor 32 Tahun 2004 Tentang Pemerintah Daerah. Seiring berjalannya waktu, Undang-Undang Nomor 32 Tahun 2004 Tentang Pemerintah Daerah tidak sesuai lagi dengan perkembangan keadaan, ketatanegaraan, dan tuntutan penyelenggaraan pemerintahan daerah sehingga Undang-Undang ini perlu diganti. Sehingga pada tahun 2014 diterbitkan Undang-Undang Republik Indonesia Nomor 23 Tahun 2014 Tentang Pemerintah Daerah sebagai pengganti atas Undang-Undang Nomor 32 Tahun 2004 Tentang Pemerintah Daerah.

Undang-Undang Nomor 23 Tahun 2014 Tentang Pemerintahan Daerah yang menggantikan Undang-Undang Nomor 32 Tahun 2004 Tentang Pemerintah Daerah telah mengalami sedikit perubahan dengan ditetapkannya Peraturan Pemerintah Pengganti Undang-Undang Republik Indonesia Nomor 2 Tahun 2014 Tentang Perubahan Atas UndangUndang Nomor 23 Tahun 2014 Tentang Pemerintah Daerah.

Selain Undang-Undang dan Peraturan Pemerintah Pengganti Undang-undang (PERPU) terdapat beberapa peraturan yang merupakan dasar hukum pemekaran daerah seperti Peraturan Pemerintah Republik Indonesia Nomor 79 Tahun 2005 Tentang Pedoman dan Pengawasan

${ }^{3}$ Moh.Kusnardi SH, Hermaily Ibrahim SH. Pengantar Hukum Tata Negara Indonesia. Jakarta Pusat: Pusat Study Hukum Tata Negara Fakultas Hukum Universitas Indonesia. 1983. HIm.101 
Penyelenggaraan Pemerintah Daerah yang merupakan ketentuan dalam melaksanakan Undang-Undang.

Selain itu juga terdapat Peraturan Mentri Dalam Negeri Nomor 31 Tahun 2006 Tentang Pembentukan, Penghapusan, dan Penggabungan Kelurahan. Pembentukan kelurahan sekurang-kurangnya memenuhi syarat: ${ }^{4}$

1. jumlah penduduk;

2. Iuas wilayah;

3. bagian wilayah kerja;

4. sarana dan prasarana pemerintahan.

Dimana dalam peraturan ini dijelaskan bahwa Kelurahan dibentuk di wilayah kecamatan. Pembentukan kelurahan dapat berupa penggabungan beberapa kelurahan atau bagian kelurahan yang bersandingan, atau pemekaran dari satu kelurahan menjadi dua kelurahan atau lebih sebagaimana di Jelaskan dalam Peraturan Pemerintah Nomor 73 Tahun 2005 Tentang Kelurahan yang mengatur lebih detail terkait kelurahan.

\section{TUJUAN PEMEKARAN DAERAH}

Dalam konteks otonomi daerah, keberadaan Pemerintah Daerah (Pemda) bertujuan untuk menyediakan pelayanan prima dan memfasilitasi proses pemberdayaan masyarakat ${ }^{5}$. Dalam pelaksanaan Desentralisasi dilakukan penataan Daerah yang bertujuan untuk: 6

1. Mewujudkan efektivitas penyelenggaraan Pemerintahan Daerah;

2. Mempercepat peningkatan kesejahteraan masyarakat;

3. Mempercepat peningkatan kualitas pelayanan publik;

4. Meningkatkan kualitas tata kelola pemerintahan;

5. Meningkatkan daya saing nasional dan daya saing Daerah; dan

\footnotetext{
${ }^{4}$ Peraturan Mentri Dalam Negeri Nomor 31 Tahun 2006 Tentang Pembentukan, Penghapusan, dan Penggabungan Kelurahan.

Kristian Widya Wicaksono, Administrasi dan Birokrasi Pemerintah, Yogyakarta:Graha IImu Cet 1 2006. hlm. 41

${ }^{6}$ Undang-Undang Nomor 23 Tahun 2014 Tentang Pemerintah Daerah.
} 
6. Memelihara keunikan adat istiadat, tradisi, dan budaya Daerah.

Penataan Daerah terdiri atas Pembentukan Daerah dan penyesuaian Daerah yang dilakukan berdasarkan pertimbangan kepentingan strategis nasional. Pembentukan Daerah sebagaimana dimaksud dalam berupa: ${ }^{7}$

1. Pemekaran Daerah; dan

2. Penggabungan Daerah.

Persyaratan dasar kewilayahan meliputi luas wilayah minimal, jumlah penduduk minimal, batas wilayah, Cakupan Wilayah dan batas usia minimal Daerah provinsi, Daerah kabupaten/kota, dan Kecamatan. Persyaratan dasar kapasitas Daerah adalah kemampuan Daerah untuk berkembang dalam mewujudkan kesejahteraan masyarakat. Cakupan Wilayah meliputi paling sedikit 5 (lima) Daerah kabupaten/kota untuk pembentukan Daerah provinsi, paling sedikit 5 (lima) Kecamatan untuk pembentukan Daerah kabupaten; dan paling sedikit 4 (empat) Kecamatan untuk pembentukan Daerah kota. Batas usia minimal meliputi:

1. batas usia minimal Daerah provinsi 10 (sepuluh) tahun dan Daerah kabupaten/kota 7 (tujuh) tahun terhitung sejak pembentukan; dan

2. batas usia minimal Kecamatan yang menjadi Cakupan Wilayah Daerah kabupaten/kota 5 (lima) tahun terhitung sejak pembentukan.

\section{AKIBAT H UKUM PEMEKARAN WILAYAH}

Akibat hukum adalah suatu akibat yang ditimbulkan oleh hukum, terhadap suatu perbuatan yang dilakukan oleh subjek hukum. Akibat hukum merupakan suatu akibat dari tindakan yang dilakukan, untuk memperoleh suatu akibat yang diharapkan oleh pelaku hukum. Akibat hukum adalah akibat yang ditimbulkan oleh peristiwa hukum. Karena suatu peristiwa hukum disebabkan oleh perbuatan hukum, sedangkan suatu perbuatan hukum juga dapat melahirkan suatu hubungan hukum, maka akibat hukum juga dapat dimaknai sebagai suatu akibat yang

\footnotetext{
${ }^{7}$ Undang-Undang Nomor 23 Tahun 2014 Tentang Pemerintah Daerah.
} 
ditimbulkan oleh adanya suatu perbuatan hukum dan/atau hubungan hukum.

Perbuatan hukum adalah segala perbuatan subjek hukum yang secara sengaja dilakukan oleh subjek hukum dan menimbulkan hak dan kewajiban. Perbuatan hukum terbagi dua terdiri dari: 8

1. Perbuatan hukum sepihak, yaitu perbuatan hukum yang dilakukan oleh salah satu pihak saja dan menimbulkan hak-dan kewajiban pada salah satu pihak pula.

2. Perbuatan hukum dua pihak, ialah perbuatan hukum yang dilakukan oleh dua pihak dan menimbulkan hak-hak dan kewajiban kewajiban bagi kedua belah pihak.

\section{Akibat Hukum Pemekaran Kelurahan Di Kecamatan Tampan Kota Pekanbaru.}

Kota Pekanbaru sebagai salah satu kota administratif di Indonesia yang baru saja melakukan otonomi daerah dengan melakukan pemekaran kelurahan Di Kecamatan Bukit Raya, Kecamatan Marpoyan Damai, Kecamatan Tampan, Kecamatan Rumbai, Kecamatan Rumbai Pesisir, Kecamatan Tenayan Raya, Kecamatan Payung Sekaki dengan membentuk kelurahan yang berasal dari penggabungan beberapa kelurahan atau bagian kelurahan yang bersanding yaitu pada tanggal 04 April 2016 ditetapkan Peraturan Daerah Kota Pekanbaru No 6 Tahun 2016 Tentang Pembentukan Kelurahan Di Kota Pekanbaru yang memekarkan kelurahan di Kecamatan Tampan dari 4 (empat) Kelurahan menjadi 9 (Sembilan) Kelurahan.

Adanya pembentukan Kelurahan di Kecamatan Tampan Kota Pekanbaru yang merupakan salah satu bentuk penataan daerah memyebabkan akibat hukum yang secara langsung dirasakan oleh masyarakat sebagai individu yang harus patuh terhadap kebijakan

8 Kansil.Pengantar Ilmu Hukum dan Tata Hukum Indonesia. Jakarta:Balai Pustaka 1989 hlm. 119 
pemerintah. Adanya pemekaran kelurahan yang menyebabkan perubahan alamat pada tempat tinggal masyarakat mengharuskan masyarakat untuk melakukan perubahan alamat pada dokumen kependudukan sesuai dengan daerah pemekaran yang kemudian juga harus kembali meyesuaikan data lain sesuai dengan perubahan yang dilakukan.

Dalam Peraturan Daerah Kota Pekanbaru Nomor 5 Tahun 2008 Tentang Penyelenggaraan Administrasi Kependudukan Pasal 6 disebutkan bahwa "Dalam hal terjadi perubahan alamat penduduk, Instansi Pelaksana wajib menyelenggarakan penerbitan perubahan dokumen Pendaftaran Penduduk". Perubahan alamat penduduk yang terjadi akibat pemekaran menyebabkan masyarakat harus melakukan perubahan dokumen kependudukannya seperti Kartu Keluarga (KK) dan Kartu Tanda Penduduk (KTP) yang kemudian juga harus merubah seluruh dokumen lainnya sebagaimana dalam pengurusannya memakan waktu yang cukup lama dan dalam berbagai hal akan berakibat terhadap berbagai administrasi lain baik dalam lingkungan pemerintahan Kota Pekanbaru mapun lintas sektor yang tidak lagi dibawah naungan atau tanggung jawab pemerintah kota pekanbaru.

Berkaitan dengan perubahan alamat yang terjadi Di Kecamatan Tampan Kota Pekanbaru karena adanaya pemekaran wilayah berdasarkan Peraturan Daerah Kota Pekanbaru No 16 Tahun 2016 Tentang Pembentukan Kelurahan Di Kota Pekanbaru mengakibatkan masyarakat harus melakukan perubahan alamat pada dokumen administrasi kependudukan masyarakat dari alamat sebelum pemekaran ke alamat setelah pemekaran. Berdasarkan hal ini penulis menanyakan kepada 150 orang responden mengenai pengetahuan masyarakat tentang keharusan perubahan alamat pada dokumen administrasi kependudukan ini terutama Kartu Keluarga (KK) dan Kartu Tanda Penduduk. 
Table 4.1

Masyarakat Harus Merubah Kartu Keluarga (KK) dan Kartu Tanda Penduduk (KTP) Akibat Pemekaran Kelurahan Di Kecamatan Tampan Kota Pekanbaru

\begin{tabular}{|c|c|c|c|}
\hline No & Jawaban & Jumlah & Persentase \\
\hline 1. & $\mathrm{Ya}$ & 126 Orang & $84 \%$ \\
\hline 2. & Tidak & 24 Orang & $16 \%$ \\
\hline & JUMLAH & 150 Orang & $100 \%$ \\
\hline
\end{tabular}

Berdasarkan tabel di atas dapat dilihat bahwa 126 Orang (84\%) dari 150 Orang responden mengetahui tentang keharusan merubah dokumen administrasi kependuduka $n$ yaitu Kartu Keluarga (KK) dan Kartu Tanda Penduduk (KTP) yang berubah alamat akibat pemekaran kelurahan. Berkaitan dengan hal ini pemerintah Kota Pekanbaru melalui Kelurahan telah memberitahukan kepada masyarakat terkait keharusan untuk merubah Kartu Keluarga (KK) dan Kartu Tanda Penduduk (KTP) sebagaimana yang dijelaskan kan oleh Lurah Air Putih yang menyatakan bahwa: "kami telah menghibau seluruh warga untuk merubah dokumen administrasi kependudukan seperti Kartu Keluarga (KK) dan Kartu Tanda Penduduk di sambutan-sambutan setiap kegiatan baik di masjid maupun di saat gotong royong bersama warga dan di berbagai kesempatan lainnya". 9

Berdasarkan wawancara yang penulis lakukan kepeda beberapa responden yang mengetahui keharusan merubah dokumen administrasi kependudukan akibat pemekaran seperti yang disampaikan Bapak Muhammad Alim, bahwa masyarakat telah diberitahukan oleh aparat pemerintah baik Lurah maupun RT di lingkungan tempat tinggalnya dalam sambutan-sambutan yang diberikan pada berbagai kegiatan. ${ }^{10}$ Dengan adanya keharusan untuk merubah Administrasi Kependudukan seperti

\footnotetext{
${ }^{9}$ Wahyu Idris. Wawancara. Lurah Air Putih Rabu, 23 mei 2018 Pukul 14.40 WIB

${ }^{10}$ Huhammad Alim. Ketua RT 02 RW 06 Kelurahan Tuah Madani. Wawancara. Pekanbaru 20 Mei 2018. Pukul 20:21 WIB.
} 
Kartu keluarga (KK) dan Kartu Tanda Keluarga (KTP) yang diakibatkan dari adanya pemekaran kelurahan masyarakat di Kecamatan Tampan, masyarakat mengalami berbagai kesulitan dalam pengurusannya sebagimana jawaban dari responden.

Tabel 4.2

Masyarakat Mengalami Kesulitan Dalam Pengurusan Administrasi Kependudukan Akibat Pemekaran Kelurahan Di Kecamatan Tampan Kota Pekanbaru.

\begin{tabular}{|l|l|c|c|}
\hline No & Jawaban & Jumlah & Persentase \\
\hline 1. & Ya & 122 & $81 \%$ \\
\hline 2. & Tidak & 28 & $19 \%$ \\
\hline \multicolumn{2}{|c|}{ JUMLAH } & 150 Orang & $100 \%$ \\
\hline \multicolumn{2}{l}{ Sumber: Hasil penyebaran angket kepada responden }
\end{tabular}

Dari tabel diatas dapat dilihat bahwa sebanyak 122 orang responden (81\%) masyarakat menjawab (Ya) bahwa mereka mengalami kesulitan dalam pengurusan KK dan KTP dan sebanyak 28 orang (19\%) responden menjawab (Tidak). Berdasarkan jawaban tersebut penulis juga mewawancarai beberapa responden yang menjawab (Ya) bahwa ia mengalami kesulitan diantaranya adalah Bapak Makmur Gharib yang menyatakan bahwa pengurusan perubahan KK dan KTP itu sangat ribet dan waktu pengurusannya juga lama, jadwal kerja mereka (petugas perubahan dokumen) sama dengan jadwal kerja saya, sementara saya sangat sulit untuk meninggalkan pekerjaan saya di pelalawan untuk mengurus KK dan KTP ini. ${ }^{11}$

Berdasarkan penjelasan tersebut dapat dilihat bahwa dalam pengurusan perubahan dokumen administrasi kependudukan menyulitkan masyarakat sehingga masrakat tidak mengurusnya apabila tidak ada keperluan yang mengharuskan dan memerlukan dokumen perubahan itu. Selain itu dalam Pengurusan perubahan ini hal yang selalu terjadi adalah kurang nya blangko, seperti apa yang dikatakan oleh lurah Binawidya yang menyatakan bahwa kendala dalam pembuatan KTP adalah blangko

\footnotetext{
${ }^{11}$ Makmur Gharib. Warga Binawidya. Wawancara.26 Mei 201820.10 WIB
} 
yang kurang, tanpa adanya pemekaran sekalipun kendala dalam pembuatan KTP adalah kurangnya blangko.

Dengan adanya pemekaran wilayah menyebabkan antusias mayarakat dalam pengurusan KTP semangkin tinggi terutama ketika ada keperluan administrasi yang membutuhkan KTP. ${ }^{12}$ Pemerintah sebagai penyelenggara administrasi kependudukan masyarakat seharusnya lebih peka dengan apa yang dibutuhkan masyarakat, jika masyarakat merasa kesulitan dalam menjalankan kebijakan yang ditetapkan pemerintah maka seharusnya pemerintah membuat kebijakan untuk memudahkan urusan masyarakat misalkan diadakannya perubahan dokumen administrasi kependudukan keliling yang di laksanakan di tiap Kelurahan maupun RW yang tentunya juga dilakukan dihari libur sehingga tidak mengganggu pekerjaan masyarakat, atau minimal membuka stand perubahan administrasi kependudukan ditempat keramaian yang sering dikunjungi masyarakat dan membuka jam pelayanan di hari libur guna perubahan dokumen kependudukan yang terjadi perubahan akibat adanya pemekaran yang dilakukan dalam hal penataan daerah dan pelaksanaan otonomi daerah.

Sejalan dangan hal tersebut penulis juga menanyakan kepada masyarakat apakah masyarakat telah melakukan perubahan dokumen administrasi kependudukan atau belum melalui kuisioner yang penulis sebar sebagaimana dapat dilihat pada tabel dibawah ini.

Tabel 4.3

Apakah Bapak/lbu Telah Melakukan Perubahan Alamat pada Dokumen Administrasi Kependudukan (KK) dan (KTP) Akibat Pemekaran Kelurahan Di Kecamatan Tampan Kota Pekanbaru?

\begin{tabular}{|l|l|c|c|}
\hline No & \multicolumn{1}{|c|}{ Jawaban } & Jumlah & Persentase \\
\hline 1. & Ya & 96 Orang & $64 \%$ \\
\hline 2. & Tidak & 54 Orang & $36 \%$ \\
\hline \multicolumn{2}{|c|}{ JUMLAH } & 150 Orang & $100 \%$ \\
\hline
\end{tabular}

Sumber : Hasil penyebaran angket kepada responden

${ }^{12}$ Lurah Tuah Madani 
Berdasarkan tabel di atas dapat dilihat bahwa 96 Orang (64\%) Responden dalam penelitian ini menyatakan telah melakukan perubahan alamat pada dokumen administrasi kependudukannya yaitu KK dan KTP sedang kan 36\% lainnya yaitu sebanyak 64 Orang menjawab tidak melakukan perubahan alamat pada dokumen admistrasi kependudukannya.

Adapun kebanyakan masyarakat yang melakukan perubahan alamat pada Kartu Keluarga (KK) dan Kartu Tanda Penduduknya (KTP) dikarena adanya keperluan yang mengharuskan untuk melakukan perubahan alamat seperti yang dinyatakan oleh Lurah Tuah Madani bahwa " masyarakat melakukan perubahan alamat KK dan KTP nya apabila ada kepentingan atau keperluan yang membutuhkan KK dan KTP seperti dalam hal penerimaan bantuan dari pemerintah, pengurusan BPJS, Pendaftaran sekolah anak berdasarkan kuota tempatan. ${ }^{13}$

Hal ini sesuai dengan yang disampaikan oleh Kepala UPTD KecamatanTampan yang menyatakan bahwa " masyarakat melakukan perubahan KK dan KTP apabila ada keperluan, bahkan banyak masyarakat yang mengurusnya ketika kepentingannya sangat mendesak sehingga menuntut untuk cepat selesai padahal untuk pengurusan itu semua ada SOP nya. ${ }^{14}$

Standar operasional prosedur pengurusan Kartu Keluarga (KK) dan Kartu Tanda Penduduk (KTP) adalah 14 hari kerja sebagaimana dijelaskan juga oleh Kepala UPTD Kecamatan Tampan " salah satu akibat yang terjadi dengan adanya pemekaran adalah banyaknya antusias masyarakat untuk merubah data kependudukan yang tentunya dalam penerbitan itu tidak dapat sesuai dengan SOP nya (Standar Operasional Prosedur) misalnya dalam penerbitan KK dan KTP yang 14 (empat belas)

${ }^{13}$ Ahmad Zunaidi Zaher. Lurah Tuah Madani. Wawancara. 24 Mei 201814.03 WIB 11.36

14 Tengku Ruzen,SE.(Kepala UPTD Kec Tampan). Wawancara. 23-Mei-2018. 
hari kerja tentu saking banyaknya masyarakat yang ingin merubah tentu tidak lagi sesuai SOP (Standar Operasional Prosedur). ${ }^{15}$

Dalam Proses perubahan Kartu Keluarga (KK) dan Kartu Tanda Penduduk (KTP) masyarakat dapat langsung menuju UPTD Kecamatan tampan dengan membawa Rekom atau surat pengantar dari RT, Rekom atau pengantar dari Lurah, dan kemudian mengisi formulir pengurusan perubahan Kartu Keluarga (KK) dan Kartu Tanda Penduduk (KTP). Sebagaimana dijelaskan oleh kepala UPTD Kecamatan Tampan Kota Pekanbaru proses perubahan Kartu Keluarga (KK) dan Kartu Tanda Penduduk (KTP) sesuai SOP nya (Standar Operasional Prosedur) harus ada rekom dari RT yang menyatakan ada perubahan karena pemekaran, rekom Lurah, rekom Camat kemudian mengisi formulir baru kita proses.

Seharusnya pemerintah mampu mengatasi hal ini dengan menjalin kerjasama baik lintas sektor maupun sesama pemerintahan untuk memudahkan segala urusan yang merupakan akibat dari adanya pemekaran kelurahan yang merupakan kebijakan pemerintah untuk samasama disukseskan sehingga terwujudlah tujuan dari kebijakan tersebut.

Tabel 4.4

Masyarakat Harus Merubah Alamat Pada STNK dan BPKB Yang Belum Sesuai Dengan KK dan KTP Yang Baru

\begin{tabular}{|c|c|c|c|}
\hline No & Jawaban & Jumlah & Persentase \\
\hline 1. & Ya & 117 & $78 \%$ \\
\hline 2. & Tidak & 33 & $22 \%$ \\
\hline & JUMLAH & 150 Orang & $100 \%$ \\
\hline
\end{tabular}

Berdasarkan tabel diatas dapat dilihat bahwa 117 orang responden (78 \%) masyarakat menjawab (Ya) terkait keharusan untuk merubah alamat pada STNK dan BPKB sesuai dengan alamat baru setelah pemekaran sedangkan 33 orang responden (22\%) menyatakan tidak harus merubah Alamat pada STNK dan BPKB sesuai dengan KK dan KTP yang telah dirubah alamatnya setelah pemekaran. Adapun menurut 11.36

15 Tengku Ruzen,SE.(Kepala UPTD Kec Tampan). Wawancara. 23-Mei-2018. 
beberapa responden yang menyatakan tidak harus merubah alamat pada STNK dan BPKB seperti yang katakana lbu Sri bahwa mereka menganggap tidak perlu dilakaukan perubahan itu, nanti saja ketika bayar pajak 5 tahunan kan nanti STNK baru, disitu baru kita sesuaikan. ${ }^{16}$

Begitupun Pak Ario yang tidak merubah STNK nya karena pemekaran ia menyatakan bahwa mobil saya baru diurus pajaknya 2017 lalu dan masih menggunakan data sebelum pemekaran, saya tidak merubahnya jika tidak benar-benar genting, pertama saya kerja, tidak ada waktu untuk mengurusnya dan yang kedua itu bayar tidak gratis sekitar Rp 150.000 sampai Rp 200.000 itu biayanyakan padahal kan rumah saya juga tidak pernah pindah sudah belasan tahun saya di sini, rumah saya juga tetap tidak pernah pindah kalo saya harus merubah lagi ya ribet dan butuh biaya belum motornya lagi. Jadi mukin nanti saya akan merubahnya kalau ada keperluannya untuk itu, sekarang masih belum. ${ }^{17}$

Adapun masyarakat yang melakukan perubahan alamat pada STNK dan BPKB karena mereka ketika membayar pajak kendaraan yang syaratnya membawa STNK dan KTP ketika dilihat petugas adanya ketidak samaan antara KTP dan STNK maka mereka mengharuskan untuk menysuaikan STNK nya dahulu.

Sehuungan dengan itu, masyarakat yang tidak melakukan perubahan alamat pada STNK dan BPKB sesuai KTP baru setelah perubahan akibat pemekaran akan kesulitan dalam membayar pajak kendaraannya seperti yang dijelaskan oleh pak Gofur Noer Nasution bahwa apabila masyarakat yang akan membayar pajak kendaraan harus membawa STNK asli dan KTP yang kemudian apabila STNK dan KTP tidak sesuai maka harus merubah STNK terlebih dahulu. ${ }^{18}$

\footnotetext{
${ }^{16}$ Sri. Warga Perumahan Citra Permata Blok B2. Wawancara. 28 mei 201811.05 WIIB

${ }^{17}$ Ario Wibowo. Warga Perumahan Ataya 2 JL. Melati RT 02 RW 09 Kelurahan Bina Widya. Wawancara. 04 Juni 2018.

18. Gofur Noer Nasution. (Pegawai SAMSAT Cabang Pekanbaru Barat) . Wawancara. 24 Mei 2018. 11.10
} 
Tabel 4.5

Masyarakat Harus Membayar Biaya Perubahan Alamat Surat Menyurat Baik Kendaraan Maupun Surat Tanah Yang Berada Di Wilayah Kelurahan Di Kecamatan Tampan Hasil Pemekaran.

\begin{tabular}{|l|l|c|c|}
\hline No & Jawaban & Jumlah & Persentase \\
\hline 1. & Ya & 150 & $100 \%$ \\
\hline 2. & Tidak & - & - \\
\hline \multicolumn{2}{|c|}{ Jumlah } & 150 & $100 \%$ \\
\hline
\end{tabular}

Sumber : Hasil penyebaran angket kepada responden

Berdasarkan tabel diatas mayoritas responden menyatakan benar bahwa mereka harus membayar biaya perubahan tersebut.Pemekaran Kelurahan yang merupakan kebijakan pemerintah mengakibatkan masyarakat harus merubah Dokumen Administrasi Kependudukan yang kemudian juga harus merubah berbagai dukumen lainnya. seharusnya pemerintah sebagai pengambil kebijakan harus memberikan kemudahan dalam berbagai urusan yang merupakan akibat dari kebijakan yang ditentukan untuk meminimalisir akibat yang negative bagi masyarakat.

\section{FAKTOR-FAKTOR PENGHAMBAT DALAM PERUBAHAN ALAMAT YANG DISEBABKAN PEMEKARAN KELURAHAN DI KECAMATAN TAMPAN KOTA PEKANBARU}

Adapun beberapa faktor penghambat dalam perubahan alamat yang disebabkan pemekaran kelurahan di kecamatan tampan kota pekanbaru diantaranya sebagai berikut :

1. Pemekaran kelurahan yang menyebabkan terjadinya perubahan alamat menyebabkan meningkatkan jumlah masyarakat yang akan mengubah data kependudukan.

Sebagaimana dijelaskan oleh Lurah Tuan Madani "bahwa kami dengan adanya pemekaran ini melalukan sosialisasi kepada masyarakat terkait perubahan KK dan KTP di awal pemekaran belum bisa dilakukan pengurusan perubahan karena ada penyesuaian data dipusat ketika sudah bisa dilakukan perubahan 
maka kami beritahukan kepada masyarakat bahwa pengurusan KK dan KTP sudah bisa dilakukan. ${ }^{19}$

2. Pengurusan perubahan dokumen itu tidak dapat diselesaikan sesuai dengan standar operasional prosedur yaitu harus selesai dalam waktu 14 hari sebagaimana yang ditemukan dilapangan dalam penelitian ini lamanya waktu pengurusan Kartu Keluarga (KK) dan Kartu Tanda Penduduk (KTP) lebih dari 14 kerja yang artinya tidak sesuai dengan peraturan (Standar Operasional Prosedur) yang ada dan tentunya menghambat berbagai urusan masyarakat yang membutuhkan Kartu Keluarga (KK) dan Kartu Tanda Penduduk (KTP). Adapun waktu pengurusan perubahan dokumen administarasi kependudukan yang standarnya 14 hari kerja karna banyaknya warga yang mengajukan perubahan maka lama penurusannya sekitar 1 (satu) bulan bahkan paling lama hampir mencapai 2 (dua) bulan.

3. Kurangnya Blangko KTP-Elektronik selalu menjadi kendala dalam pengurusan KTP masyararakat. Meningkatnya jumlah masyarakat yang melakukan pengurusan perubahan dokumen administrasi kependudukan terkendala di blangko yang kurang dan sering kehabisan sehingga juga semakin memperlambat waktu pengurusan yang akibatnya tidak lagi sesuai dengan SOP pengurusanya. Sebagaimana dijelaskan oleh Lurah Tuah Madani bahwa sejak mulainya beralih ke KTP elektronik blangko selalu menjadi kendalanya apalagi ditambah dengan pemekaran yang mengakibatkan warga harus merubah alamat KTP nya. Sehingga semakin banyak kekurangannya dan tentunya waktu pengurusannya menjadi semakin lama.

4. Kurangnya sarana prasarana yang ada. Sarana dan prasarana merupakan salah satu dari standar pelayanan publik.Penyediaan

${ }^{19}$ Ahmad Zunaidi Zaher. Lurah tuah madani. Wawancara. 24 Mei 201814.03 
sarana dan prasarana pelayanan yang memadai oleh penyelenggara pelayanan publik sangat menentukan dan menunjang keberhasilan penyelenggaraan pelayanan seharusnya menyiapakan sarana prasarana yang memadai untuk tercapai tujuan-tersebut seperti misalnya Kantor Kelurahan yang merupakan tempat pelayanan masyarakat menggunakan rumah yang harusnya difungsikan sebagai tempat tinggal dijadikan kantor untuk tempat pelayanan yang ruangannya cenderung kecil dan sempit bahkan lokasi parkirnya tidak ada atau sanggar sempit. Hal ini juga dijelaskan oleh Lurah Tuah Madani yang menyatakan bahwa "pemerintah dalam pemekaranan ini kurang menyediakan saranan prasarana nya seperti kantor kelurahan sebagai tempat pelayanan masyarakat belum memadai, menggunakan rumah yang seharusnya untuk tempat tinggal bahkan lokasi parkir pun sangat sempit. Untuk parkir pegawai saja sudah penuh. ${ }^{20}$

5. Kurangnya pengetahuan pegawai terhadap kebijakan yang harus dijalankan sebagaimana dijelaskan oleh Ketua UPTD Kecamatan Tampan bahwa sering kali masyarakat datang mengurus dokumen kependudukan ke UPTD tetapi berkas yang merupakan syarat untuk pengurusan masih kurang. Sehingga masyarakat harus kembali lahi kekelurahan untuk kembali mengurus persyaratan yang diperlukan untuk mengurus dokumen yang diperlukan.

6. Kurangnya kesadaran dan partisipasi masyarakat dalam melaksanakan kebijakan yang ditetapkan pemerintah sebagaimana telah dijelaskan sebelumnya bahwa kebnayakan masyarakat akan melakukan perubahan dokumen kependudukan apabila ada kepentingan yang mendesak. Dari penjelasan diatas dapat dilihat bahwa diperlukan peran serta masyarakat untuk mewujudkan keberhailan atas kebijakan yang ditetapkan pemerintah dan

${ }^{20}$ Lurah tuah madani. Wawancara. 24-Mei 201814.03 WIB 
pemerintah harus lebih memahami apa yang dibutuhkan masyarakat.

\section{KESIMPULAN}

1. Perubahan alamat penduduk yang terjadi akibat pemekaran menyebabkan masyarakat harus melakukan perubahan dokumen kependudukannya seperti Kartu Keluarga (KK) dan Kartu Tanda Penduduk (KTP) yang kemudian juga harus merubah seluruh dokumen lainnya sebagaimana dalam pengurusannya memakan waktu yang cukup lama dan dalam berbagai hal akan berakibat terhadap berbagai administrasi lain baik dalam lingkungan pemerintahan Kota Pekanbaru mapun lintas sektor yang tidak lagi dibawah naungan atau tanggung jawab pemerintah kota pekanbaru. Berkaitan dengan perubahan alamat yang terjadi Di Kecamatan Tampan Kota Pekanbaru karena adanaya pemekaran wilayah berdasarkan Peraturan Daerah Kota Pekanbaru No 16 Tahun 2016 Tentang Pembentukan Kelurahan Di Kota Pekanbaru mengakibatkan masyarakat harus melakukan perubahan alamat pada dokumen administrasi kependudukan masyarakat dari alamat sebelum pemekaran ke alamat setelah pemekaran.

2. Faktor-Faktor Penghambat Dalam Perubahan Alamat Yang Disebabkan Pemekaran Kelurahan Di Kecamatan Tampan Kota Pekanbaru :

a. Pemekaran kelurahan yang menyebabkan terjadinya perubahan alamat menyebabkan meningkatkan jumlah masyarakat yang akan mengubah data kependudukan

b. Kurangnya Blangko KTP-Elektronik dalam perubahan dokumen administrasi kependudukan dan sering kehabisan sehingga juga semakin memperlambat waktu pengurusan yang akibatnya tidak lagi sesuai dengan SOP pengurusanya.

c. Kurangnya sarana prasarana yang memadai oleh penyelenggara pelayanan publik 
d. Kurangnya pengetahuan pegawai terhadap kebijakan yang harus dijalankan.

e. Kurangnya kesadaran dan partisipasi masyarakat dalam melaksanakan kebijakan yang ditetapkan pemerintah.

\section{SARAN}

Dari uraian dan kesimpulan diatas, maka penulis memberikan saran sebagai berikut :

1. Kepada pemerintah agar dalam membuat kebijakan tidak hanya cukup sampai kebijakan itu dilakukan tetapi tetap adakan pemantauan atas kebijakan tersebut dan senantiasa mencari tahu bangaimana kebijakan itu dijalankan apakah sesuai dengan harapan atau tidak dan agar segera mengatasi berbagai kendala yang terjadi dilapangan.

2. Pemerintah Kota Pekanbaru hendaknya melakukan kerjasama dengan sektor-sektor lain yang tidak dibawah naungan atau tanggung jawab pemerintah Kota Kekanbaru untuk hal-hal yang memudahkan masyarakat dalam hal pelaksanaan dari kebijakan yang ditetapkan ataupun akibt dari kebijakan yang ditetapkan.

3. Pemerintah dalam membuat kebijakan hendaknya menyiapkan berbagai sarana prasarana untuk menunjang kesuksesan atas kebijakan yang ditetapkan sehingga terkesan lebih siap atas kebijakan yang ditetapkan tersebut.

4. Mayarakat harus berpartisipasi dalam menjalankan kewajibanya sebagai warga Negara untuk menjalankan kebijakan yang ditetapkan pemerintah sehingga hunguan timbal balik antara pemerintah dan mayarakat dapat berjalan dengan baik. Tidak saling menuntut hak tanpa menjalankan kewajiban. 


\section{DAFTAR PUSTAKA}

Ali, Zainudin. 2009. Metode Penelitian Hukum. Palu : sinar grafika.

Ashshofa, Burhan. 2010. Metode Penelitian Hukum. Jakarta: Rineka Cipta.

http://tampan.pekanbaru.go.id/2015-08-14-02-58-43/profil-kecamatan

Ismanto, Gery dkk. 2013. Pendidikan Pancasila. Pekanbaru:CV.Mulia Indah Kemala,

Ismail, Mohamad. 1999. "Kualitas Pelayanan Masyarakat: Konsep dan Implementasinya". Dalam Miftah Thoha (ed). Administrasi Negara, Demokrasi, dan Masyarakat Madani. Jakarta: Lembaga Administrasi Negara.

Peraturan Daerah Kota pekanbaru Nomor 4 Tahun 2016

Kusdarini, Eny. 2001. Dasar - Dasar Hukum Administrasi Negara dan Asas - Asas Umum Pemerintahan yang Baik. Yogyakarta: UNY Press.

Kansil. 1989. Pengantar IImu Hukum dan Tata Hukum Indonesia. Jakarta:Balai Pustaka

Kurniawan, Agung. 2005. Transformasi Pelayanan Publik. Yogyakarta: Pembaharuan.

Kusnardi, Moh. dan Hermaily Ibrahim. 1983. Pengantar Hukum Tata Negara Indonesia. Jakarta Pusat: Pusat Study Hukum Tata Negara Fakultas Hukum Universitas Indonesia.

Moenir, H.A.S. 2002. Manajemen Pelayanan Umum di Indonesia. Bandung: Bumi Aksara.

Nawawi, Zaidan. 2013. Managemen Pemerintahan,Jakarta:Rajawali Pers.

Nurcholis, Hanif. 2005. Teori dan Pratik Pemerintahan dan Otonomi Daerah. Grasindo: Jakarta.

Nugroho, Rian. 2015. Kebijakan Publik Di Negara-Negara Berkemban.yogyakarta: Pustaka Pelajar.

Peraturan Pemerintah Nomor 73 Tahun 2005 Tentang Kelurahan

Peraturan Pemerintah Nomor 79 Tahun 2005 Tentang Pedoman Pembinaan dan Pengawasan Penyelenggaraan Pemerintah Daerah.

Peraturan Menteri Dalam Negeri Nomor 31 Tahun 2006 Tentang Pembentukan, Penghapusan, dan Penggabungan Kelurahan.

Peraturan Daerah Kota Pekanbaru Nomor 5 Tahun 2008 Tentang Penyelenggaraan Administrasi Kependudukan.

Peraturan Daerah Kota Pekanbaru Nomor 4 Tahun 2016 Tentang Pembentukan Kelurahan Di Kota Pekanbaru.

Ratminto dan Atik Septi Winarsih. 2006. Manajemen Pelayanan.Yogyakarta : Pustaka Pelajar.

Samah, Abu. 2016 Hukum Kebijakan Publik Pekanbaru: Fakultas Syariah dan Hukum

Samah, Abu. 2016. Hukum Pemerintah Daerah dan Desa Di Indonesia. Pekanbaru: Fakultas Syariah dan Hukum 
Setiawan. 2005. Dimensi-dimensi Pemerintahan Desa, Jakarta.PT. Bina Aksara.

Sinambela, Lijan Poltak. 2008. Reformasi Pelayanan Publik. Jakarta: Bumi Aksara.

Soewadji, Jusuf. 2012. Pengantar Metodologi Penelitian. Jakarta. Mitra Wacana Media.

Sorjono, Soekanto. 2004. Pengantar penelitian hukum. Jakarta. UI Press.

Tahir, Arifin. 2014. Kebijakan public \& Transparansi Penyelenggaraan Pemerintah Daerah. Bandun g:Alfabeta

Undang-undang No 23 Tahun 2014 Tentang Pemerintah Daerah.

Undang-Undang No 23 Tahun 2006 Tentang Administrasi Kependudukan.

Undang - Undang Nomor 09 Tahun 2015 tentang Pemerintah Daerah

Waluyo, Bambang. 2002. Penelitian Hukum Dalam Praktek, Jakarta: Sinar Grafika,

Wicaksono, Kristian Widya 2006 Administrasi dan Birokrasi Pemerintah, Yogyakarta:Graha IImu.

Widjaja, Haw. 2002. Otonomi Daerah dan Daerah otonom. Jakarta: PT.Raja Gravindo Persada, 